\title{
TU/e EmonOWEN

\section{Lattice parameters and cation distribution of solid solutions of calcium and lead hydroxyapatite}

Citation for published version (APA):

Verbeeck, R. M. H., Lassuyt, C. J., Heijligers, H. J. M., Driessens, F. C. M., \& Vrolijk, J. W. G. A. (1981). Lattice parameters and cation distribution of solid solutions of calcium and lead hydroxyapatite. Calcified Tissue International, 33(3), 243-247. https://doi.org/10.1007/BF02409444

DOI:

10.1007/BF02409444

Document status and date:

Published: 01/01/1981

\section{Document Version:}

Publisher's PDF, also known as Version of Record (includes final page, issue and volume numbers)

\section{Please check the document version of this publication:}

- A submitted manuscript is the version of the article upon submission and before peer-review. There can be important differences between the submitted version and the official published version of record. People interested in the research are advised to contact the author for the final version of the publication, or visit the $\mathrm{DOI}$ to the publisher's website.

- The final author version and the galley proof are versions of the publication after peer review.

- The final published version features the final layout of the paper including the volume, issue and page numbers.

Link to publication

\section{General rights}

Copyright and moral rights for the publications made accessible in the public portal are retained by the authors and/or other copyright owners and it is a condition of accessing publications that users recognise and abide by the legal requirements associated with these rights.

- Users may download and print one copy of any publication from the public portal for the purpose of private study or research.

- You may not further distribute the material or use it for any profit-making activity or commercial gain

- You may freely distribute the URL identifying the publication in the public portal.

If the publication is distributed under the terms of Article 25fa of the Dutch Copyright Act, indicated by the "Taverne" license above, please follow below link for the End User Agreement:

www.tue.nl/taverne

Take down policy

If you believe that this document breaches copyright please contact us at:

openaccess@tue.nl

providing details and we will investigate your claim. 


\title{
Lattice Parameters and Cation Distribution of Solid Solutions of Calcium and Lead Hydroxyapatite
}

\author{
R. M. H. Verbeeck, ${ }^{1}$ C. J. Lassuyt,${ }^{1}$ H. J. M. Heijligers,${ }^{2}$ F. C. M. Driessens,${ }^{3}$ and J. W. G. A. Vrolijk ${ }^{2}$ \\ ${ }^{1}$ Laboratory for Analytical Chemistry, University of Gent, J. Plateaustraat 22, B-9000 Gent, Belgium; ${ }^{2}$ Laboratory for Physical \\ Chemistry, University of Technology, Eindhoven; and ${ }^{3}$ Institute of Dental Materials Science, Catholic University, P.O. Box 9101, \\ 6500 HB Nijmegen, The Netherlands
}

Summary. Solid solutions of calcium hydroxyapatite ( $\mathrm{CaOHA})$ and lead hydroxyapatite (PbOHA) of the formula $\mathrm{Ca}_{10-\mathrm{x}} \mathrm{Pb}_{\mathrm{x}}\left(\mathrm{PO}_{4}\right)_{6}(\mathrm{OH})_{2}$ were prepared by coprecipitation followed by heating at $800^{\circ} \mathrm{C}$ in a stream of $\mathrm{CO}_{2}$-free water vapor of $1 \mathrm{~atm}$. The samples were apatitic in the range $0<x<6$ and contained lead phosphates as a second phase at higher $\mathrm{Pb} / \mathrm{Ca}$ ratios. Lattice parameters and cation distribution of the apatitic samples were determined by $\mathrm{X}$-ray diffraction. The lattice parameters varied linearly with $\mathrm{x}$ in the range considered, whereas all $\mathrm{Pb}^{2+}$ were located in the sixfold position for cations. There was a miscibility gap in the apatite series of solid solutions in the range $1<\mathrm{x}<4$, whereas apatites in the range $6<\mathrm{x}<10$ were not stable under the conditions of preparation. It is concluded that apatites in the range $4<\mathrm{x}<6$ represent a minimum in the free energy of solid solutions between $\mathrm{CaOHA}$ and PbOHA.

Key words: Calcium hydroxyapatite - Lead hydroxyapatite - Cation distribution - Lattice parameters - Solid solutions.

Exposure to lead in food and the environment in general or in industry in particular can cause anemia [1], renal insufficiency $[2,3]$, and encephalopathy [4], the latter resulting in disturbed behavior [5]. Lead is retained in liver, kidneys, and blood, and especially in bone, teeth, and brain [6]. Infants have a relatively high retention as compared to adults [7]. Indications have been found that lead interferes with the metabolism of calcium [8-16], magnesium $[17]$, strontium [9], copper $[1,18]$, iron $[18,19]$, zinc

Send offprint requests to F. C. M. Driessens at the above address.
[20], phosphorus [8, 15], and sulfur [21, 22]. The disappearance curves for lead excretion in blood, plasma, hematic cells, and some other soft tissues can be expressed as sums of exponential functions. In contrast, lead is removed from bone tissue at a constant and extremely slow rate [23]. For this reason time integrals of body burdens of lead may well be diagnosed by determination of the lead content in bones and teeth [23-31], whereas momentary body burdens of lead should be derived rather from analyses of biochemical factors [32-34]. When lead ions are injected in the form of lead acetate, they not only interact with the calcified tissues $[35,36]$, but they also induce ectopic calcification [37, 38]. The strong capacity of lead ions to induce calcification is clearly illustrated by a case study reporting arthritis of the hip secondary to retained bullet fragments which corroded when in contact with synovial fluid [39].

Little is known about the physicochemical background of the interaction of lead ions with calcified tissues. It might be assumed that lead ions are incorporated in the apatite phase of the minerals in these tissues, as the existence of lead apatite has been established. However, Kato and Ogura [38] have shown that the first lead-containing mineral in the ectopic calcifications formed after injection of lead acetate in the rat is lead pyrophosphate. That the intensity of the characteristic X-ray diffraction peaks diminishes with time [38] might indicate that this pyrophosphate dissolves slowly whereby the dissolved ions react as yet with the apatitic mineral present in the calcification. In order to gain more insight into these processes, more basic physicochemical studies should be carried out.

Some investigators have prepared solid solutions of calcium hydroxyapatite (CaOHA) and lead hydroxyapatite (PbOHA). According to Müller [40], Narasaraju et al. [41], and Rao [42], the lattice parameters of these solid solutions both vary linearly 
with composition between those of the pure end members. On the contrary, Engel et al. [43] found that the variation of the $c$ parameter with composition deviates markedly from Vegard's law. This was attributed to the preference of $\mathrm{Pb}^{2+}$ for the sixfold position of the cation sublattices of apatite. Unfortunately, Engel et al. [43] determined the cation distribution only in one sample. In order to check this hypothesis and as a start for a systematic physicochemical study on the interaction of lead ions with $\mathrm{CaOHA}$, the present investigation was undertaken. In this study the lattice parameters and the cation distribution of solid solutions of CaOHA and $\mathrm{PbOHA}$ were determined in the most relevant composition range.

\section{Theoretical Considerations}

In the apatite structure two sublattices occur for the cation. Position I is fourfold and its Wyckhoff notation is $\mathrm{f}$, whereas position II is sixfold and is denoted by $h$. Therefore, if the chemical formula of a solid solution of lead and calcium hydroxyapatite is given by

$$
\mathrm{Ca}_{10-\mathrm{x}} \mathrm{Pb}_{\mathbf{x}}\left(\mathrm{PO}_{4}\right)_{6}(\mathrm{OH})_{2} \quad 0<\mathrm{x}<10
$$

its structural formula can be written as

$$
\mathrm{Ca}_{4-\alpha \mathrm{X}} \mathrm{Pb}_{\alpha \mathrm{x}}\left(\mathrm{Ca}_{6-(1-\alpha) \mathrm{X}} \mathrm{Pb}_{(1-\alpha) \mathrm{X}}\right) \quad\left(\mathrm{PO}_{4}\right)_{6}(\mathrm{OH})_{2}
$$

At the temperature of preparation, the equilibrium

$$
\mathrm{Ca}(\mathrm{I})+\mathrm{Pb}(\mathrm{II}) \rightleftharpoons \mathrm{Ca}(\mathrm{II})+\mathrm{Pb}(\mathrm{I})
$$

may be reached [44]. A distribution coefficient $\mathrm{K}$ can then be defined as

$$
\mathrm{K}=\frac{[6-(1-\alpha) \mathrm{x}][\alpha \mathrm{x}]}{[4-\alpha \mathrm{x}][(1-\alpha) \mathrm{x}]}
$$

If the $\mathrm{Pb}$ and $\mathrm{Ca}$ ions have no preference for either the sixfold or the fourfold position, their distribution over the corresponding sublattices will be at random whereby $K=1$. However, a preference of $\mathrm{Pb}$ for the sixfold position II and hence a preference of $\mathrm{Ca}$ for the fourfold position $\mathrm{I}$, as suggested by Engel et al. [43], would result in $K<<1$. In that case the cation distribution is most accurately determined on samples with $\mathrm{x} \leqslant 6$. A constant value for $\mathrm{K}$ throughout the composition range $0<\mathrm{x}<10$ would mean that the solid solutions are ideal in the thermodynamic sense [44]. In that case $K$ is identical to the equilibrium constant for equation (3). Both PbOHA [45, 46] and CaOHA [47] have the space group $\mathrm{P6}_{3} / \mathrm{m}$. The structure is hexagonal. Literature values for the lattice parameters a and $c$ of
$\mathrm{PbOHA}$ are summarized in Table 1. For those of $\mathrm{CaOHA}$, see [48].

\section{Materials and Methods}

Pure $\mathrm{CaOHA}$ and solid solutions of $\mathrm{CaOHA}$ and PbOHA were prepared according to the method described by Wright [51] for the preparation of solid solutions of PbOHA and strontium hydroxyapatite. The apatites were precipitated from a boiling aqueous solution of piperidine at $\mathrm{pH} 12$ by the simultaneous and slow addition of a solution containing the appropriate amounts of $\mathrm{Ca}\left(\mathrm{NO}_{3}\right)_{2}$ and $\mathrm{Pb}\left(\mathrm{NO}_{3}\right)_{2}$ and $\mathrm{a}_{3} \mathrm{PO}_{4}$ solution. The $\mathrm{pH}$ of the latter was adjusted to $\mathrm{pH} 12$ by the addition of piperidine. Reagent grade chemicals were used throughout. Further details on the method of preparation can be found elsewhere [51]. Finally, the samples were pressed into bars under $2 \times 10^{7} \mathrm{~N} \mathrm{~m}^{-2}$ and heated at $800^{\circ} \mathrm{C}$ in a stream of $\mathrm{CO}_{2}$-free water vapor of $1 \mathrm{~atm}$. After $4 \mathrm{~h}$ the samples were quenched in air, crushed, and powdered in an agate ball mill. The calcium and lead contents of the single-phase samples were determined by atomic absorption spectrometry and are summarized in Table 2.

$\mathrm{X}$-ray diffraction was carried out in the Philips Guinier XDC700 camera. The camera constant was determined with $\alpha-\mathrm{Al}_{2} \mathrm{O}_{3}$ as an internal standard. $\mathrm{CuK}_{x 1}$ radiation was used for an exposure time of about $8 \mathrm{~h}$. The films were developed in the usual way. Densitograms were recorded on the Lin/Log Densitometer DD2 (Kipp) having logarithmic sensitivity.

The densitograms were analyzed for the occurrence of second phases by comparing the $d$ values of eventual extra peaks with those of known compounds in the quaternary system $\mathrm{CaO}-\mathrm{PbO}$ $\mathrm{P}_{2} \mathrm{O}_{1}-\mathrm{H}_{2} \mathrm{O}$. The cell parameters $\mathrm{a}$ and $\mathrm{c}$ of the apatite phase were determined by measuring the position of as many apatite peaks as possible (n). A least-squares calculation on these positions

Table 1. Literature values for the lattice parameters of pure lead hydroxyapatite

\begin{tabular}{llll}
\hline Substance & $\mathrm{a}$ & $\mathrm{c}$ & Reference \\
\hline PbOHA & 9.34 & 6.87 & Narasaraju et al. [41] \\
& 9.86 & 7.22 & Rao [42] \\
& $9.84-9.88$ & $7.40-7.42$ & Bhatnagar [50] \\
& 9.89 & 7.28 & Müller [40] \\
9.868 & 7.430 & Wright [51] \\
9.877 & 7.429 & Engel [49] \\
9.879 & 7.434 & Engel [46] \\
9.878 & 7.432 & Negas and Roth [52] \\
9.877 & 7.247 & Blakeslee and Condrate [53]
\end{tabular}

Preparations of the above substances have been different and may have affected the results

Table 2. Chemical composition and substitution degree $\mathrm{x}$ of the $\mathrm{CaOHA}-\mathrm{PbOHA}$ solid solutions

\begin{tabular}{llll}
\hline $\mathrm{x}_{\text {theer }}$ & wt \% Pb & wt \% Ca & $\mathrm{x}_{\text {exp }}$ \\
\hline 1 & 15.2 & 28.8 & 0.93 \\
2 & 29.6 & 24.8 & 1.88 \\
3 & 40.5 & 20.6 & 2.76 \\
4 & 47.5 & 15.2 & 3.77 \\
5 & 56.1 & 11.3 & 4.90 \\
6 & 60.2 & 8.09 & 5.90 \\
\hline
\end{tabular}


Table 3. Phase composition and lattice parameters of the apatite phase in samples prepared in this study

\begin{tabular}{lllll}
\hline$x_{\text {theur }}$ & Second phase & $\mathrm{a}$ & $\mathrm{c}$ & $N^{\mathrm{b}}$ \\
\hline 0 & Absent & 9.416 & 6.885 & 16 \\
1 & Absent & 9.442 & 6.910 & 30 \\
2 & Absent & $9.48^{\mathrm{a}}$ & $6.94^{\mathrm{a}}$ & 20 \\
3 & Absent & $9.54^{\mathrm{a}}$ & $7.01^{\mathrm{a}}$ & 10 \\
4 & Absent & 9.572 & 7.014 & 27 \\
5 & Absent & 9.625 & 7.051 & 31 \\
6 & $\mathrm{~Pb}_{8} \mathrm{P}_{2} \mathrm{O}_{13}$ (trace) & 9.661 & 7.099 & 24 \\
\hline
\end{tabular}

"Nearly all peaks were very broad or even double

"Number of reflections used to calculate the lattice parameters

Table 4. Mean values and corresponding variances for the cation distribution parameter $\alpha$ and distribution coefficient $\mathrm{K}$ of the $\mathrm{CaOHA}-\mathrm{PbOHA}$ solid solutions

\begin{tabular}{lllll}
\hline $\mathrm{x}_{\text {theor }}$ & $\bar{\alpha}(\mathrm{x})$ & $\sigma_{\alpha(\mathrm{X})}^{2}$ & $\overline{\mathrm{K}}(\mathrm{x})$ & $\sigma_{\mathrm{K}(\mathrm{x})}^{2}$ \\
\hline 1 & 0.152 & 0.0135 & 0.279 & 0.0579 \\
2 & 0.153 & 0.0056 & 0.230 & 0.0236 \\
4 & 0.091 & 0.0058 & 0.084 & 0.0077 \\
5 & 0.075 & 0.0034 & 0.041 & 0.0023 \\
6 & 0.055 & 0.0032 & 0.013 & 0.0004 \\
\hline
\end{tabular}

produced the best fitting values for a and $\mathrm{c}$. In those instances where $\mathrm{n}>25$, the accuracy is estimated to be better than 0.003 and $0.002 \AA$ for a and $\mathrm{c}$, respectively.

In the single-phase apatitic samples the cation distributions were determined from the relative intensities of the suitable reflections in diffractograms obtained without addition of the internal standard. Peak area was taken as a measure for peak intensity. The combination of the film sensitivity and the logarithmic sensitivity of the densitometer gives an overall linear relationship between peak and reflection intensity.

As standardization of all steps in the intensity measurements is difficult, intensity ratios of pairs of reflections were used to determine the cation distribution. These pairs were chosen so that a certain preference of $\mathrm{Pb}$ ions for a certain sublattice would have an opposite effect on their intensity and so that the absorption correction and the temperature factor could be neglected. For each $x$ value and for each of the 12 chosen pairs of reflections, theoretical intensity ratios were calculated for values of $\alpha$ ranging from minimum to maximum. Lorentz polarization, multiplicity, and structure factor were taken into account. For each chosen pair of reflections the value of the distribution parameter $\alpha$ corresponding to the measured intensity ratio was then obtained by comparison with these theoretical intensity ratios. In this way 12 values for $\alpha$ and $K$ were obtained for each sample at a given $\mathrm{x}$.

\section{Results}

Since the samples with $x_{\text {theor }}>6$ were found to contain fairly large amounts of certain lead phosphates as a second phase, they were not examined further. The phase composition and the lattice pa- rameters a and $c$ of the apatite phase in the other samples prepared in this work are summarized in Table 3. At $x_{\text {theor }}=6$ a trace of second phase was observed which could be identified by comparison with data of Brixner and Foris [54]. Samples at $x_{\text {theor }}$ values of 2 and 3 showed broad and even double peaks suggesting the occurrence of a miscibility gap of the apatites in the range $1<x_{\text {theor }}<4$. However, when calculated from the position of the most sharp reflections, the estimated lattice parameters of these samples as given in Table 3 fit reasonably well within the rest of the values. The latter vary within experimental error linearly with $\mathrm{x}$ according to

$$
\begin{aligned}
\mathrm{a}= & (9.410 \pm 0.005)+(0.043 \pm 0.001) \mathrm{x} \\
& \text { with } \sigma_{\mathrm{a}}=0.006
\end{aligned}
$$

and

$$
\begin{aligned}
\mathrm{c}= & (6.880 \pm 0.005)+(0.036 \pm 0.001) \mathrm{x} \\
& \text { with } \sigma_{\mathrm{c}}=0.006
\end{aligned}
$$

where $\sigma$ represents the standard deviation of estimate.

In Table 4 , the cation distribution parameter $\alpha$ and the distribution coefficient $\mathrm{K}$ are summarized. Each value represents the mean of 12 determinations corresponding to 12 selected intensity ratios. The respective variances $\sigma_{\alpha}^{2}$ and $\sigma^{2}{ }_{K}$ are also given. From the table it is seen that within the experimental error all $\mathrm{Pb}$ ions occupy the sixfold position II. The fact that two apatite phases are probably present at $\mathrm{x}=2$ and 3 means that $\mathrm{K}$ and $\alpha$ for these samples in Table 4 are a sort of average for these two apatite phases, as the intensities of the X-ray diffraction peaks are monotonous functions of $\alpha$ and $\mathrm{K}$.

\section{Discussion}

The cell parameters for our heat-treated samples both vary linearly with $x$ within the limits of experimental error. The a parameter at $x=10$ as extrapolated from Eq. (5) agrees fairly well with literature values commonly reported for $\mathrm{PbOHA}$ (Table 1). However, there is considerable disagreement between the extrapolated value for $\mathrm{c}$ at $\mathrm{x}=10[\mathrm{Eq}$. (6)] and the c parameter of PbOHA (Table 1). Such deviation from Vegard's law indicates that $\mathrm{K}$ [Eq. (4)] differs markedly from unity. This is corroborated by the results in Table 4 showing the strong preference of the $\mathrm{Pb}$ ions for the sixfold position II in the apatite lattice and confirming the opinion of Engel et al. [43]. On this basis no ideal behavior can be expected for these solid solutions [44]. The preference of $\mathrm{Pb}^{2+}$ ions for the sixfold position II may 
be related to the fact that there is somewhat more space in position II than in position I [57].

The values for the lattice parameters of the $\mathrm{PbOHA}-\mathrm{CaOHA}$ solid solutions in Table 3 are generally $0.03 \AA$ lower than those reported by Engel et al. [43]. A calculation based on the results of Engel [46] shows that the dehydration degree of pure $\mathrm{PbOHA}$ at $800^{\circ} \mathrm{C}$ and for a partial water vapor pressure of $760 \mathrm{~mm} \mathrm{Hg}$ amounts to $3 \%$ maximum. Since the dehydration tendency of $\mathrm{PbOHA}-\mathrm{CaOHA}$ solid solutions decreases with increasing calcium content [43], it is unlikely that the lower a and c values in this study are due to a partial dehydration of the samples. The discrepancy most probably is related to a different crystal-chemical constitution of heat-treated and hydrothermally treated solids as is shown for CaOHA [53, 55].

The fact that for $x_{\text {theor }}$ values of 2 and 3 there was a doubling of most lines in the X-ray diffraction pattern is interpreted as the occurrence of a miscibility gap in the range $1<x_{\text {theor }}<4$. The formation of a superstructure around $x=3$ is not likely as it would have resulted in extra lines rather than in a doubling of lines. Moreover, such extra lines would have appeared only in a narrow compositional range around $x=3$. A miscibility gap is not uncommon in series of apatites with isomorphous substitution [56] and means that there is a maximum in the free energy of the apatites within that range. Further, the fact that our preparations in the range $6<x_{\text {theor }}$ $<10$ contained fairly large amounts of certain lead phosphates as a second phase is an indication that apatites in that range are not very stable either.

Therefore, we conclude that apatites in the range $4<\mathrm{x}_{\text {theor }}<6$ represent a minimum in the free energy between $\mathrm{CaOHA}$ and $\mathrm{PbOHA}$. Hence one should expect that incorporation of $\mathrm{Pb}^{2+}$ ions in bone and teeth results in the formation of a separate $(\mathrm{Pb}, \mathrm{Ca}) \mathrm{OHA}$ phase somewhere in the range $4<$ $\mathrm{x}_{\text {theor }}<6$, at least as far as the minerals in bone and teeth can be compared with $\mathrm{CaOHA}$. In the following study we will carry out solubility determinations on the apatites prepared in this study in order to investigate whether this hypothesis is correct for in vivo conditions or whether other, eventually hydrated solid phases (e.g., $\mathrm{PbHPO}_{4}$ ) interfere in the control of the solubility behavior.

\section{References}

1. Klander, D. S., Petering, H. G.: Anemia of lead intoxication, a role for copper, J. Nutr. 107:1779-1785, 1977

2. Campbell, B. C., Beattie, A. D., Moore, M. R., Goldberg, A., Reid, A. G.: Renal insufficiency associated with excessive lead exposure, Br. Med. J. 6059:482-485, 1977

3. Wedeen, R. P., Maesaka, J. K., Weiner, B., Lipat, G. A.,
Lyons, M. M., Vitale, L. F., Joselow, M. M.: Occupational lead nephropathy, Am. J. Med. 59:630-641, 1975

4. Goldstein, G. W.: Lead encephalopathy: the significance of lead inhibition of calcium uptake by brain mitochondria, Brain Res. 136:185-188, 1977

5. Waldron, H. A.: Lead and human behaviour, J. Ment. Defic. Res. 22:69-78, 1978

6. Momcilovix, B., Kostial, K.: Kinetics of lead retention and distribution in suckling and adult rats, Environ. Res. 8:241-220, 1974

7. Ziegler, E. E., Edwards, B. B., Jensen, R. L., Mahaffey, K. R., Fomon, S. J.: Absorption and retention of lead in infants, Pediatr. Res. 12:29-34, 1978

8. Barltrop, D., Khoo, H. E.: The influence of dietary minerals and fat on the absorption of lead, Sci. Total Environ. 6:265-273, 1976

9. Cruden, N., Stantic, M., Buben, M.: Influence of lead on calcium and strontium transfer through the duodenal wall in rats, Environ. Res. 8:203-206, 1974

10. Mahaffey, K. R., Croyer, R., Haseman, J. K.: Doseresponse to lead ingestion in rats fed low dietary calcium, $\mathrm{J}$. Lab. Clin. Med. 82:92-100, 1973

11. Meredith, P. A., Moore, M. R., Goldberg, A.: The effect of calcium on lead absorption in rats, Biochem. J. $166: 531-537,1977$

12. Batton, J. C., Conrad, M. E., Harrison, L., Nuby, S.: Effects of calcium on the absorption and retention of lead, J. Lab. Clin. Med. 91:366-376, 1978

13. Croyer, R. A.: Calcium and lead interactions: some new insights, J. Lab. Clin. Med. 91:363-365, 1978

14. Jacobson, J. L., Snowdon, C. T.: Increased lead ingestion in calcium deficient monkeys, Nature 262:51-52, 1976

15. Quarterman, J., Morrison, J. N.: The effects of dietary calcium and phosphorus on the retention and excretion of lead in rats, Br. J. Nutr. 34:351-362, 1975

16. Gruden, N., Buben, M.: Influence of lead on calcium metabolism, Bull. Environ. Contam. Toxicol. 18:303-307, 1977

17. Fine, B. P., Barth, A., Sheffet, A., Laventar, M. A.: Influence of magnesium on the intestinal absorption of lead, Environ. Res. 12:224-227, 1976

18. Klander, D. S., Petering, H. G.: Protective value of dietary copper and iron against some toxic effects of lead in rats, Environ. Health Perspect. 12:77-80, 1975

19. Ragan, H. A.: Effects of iron deficiency on the absorption and distribution of lead and cadmium in rats, J. Lab. Clin. Med. 90:700-706, 1977

20. Cerklewski, F. L., Forbes, R. M.: Influence of dietary zinc on lead toxicity in the rats, J. Nutr. 105:689-696, 1976

21. Morrison, J. N., Quarterman, J., Humphries, W. R., Mills, C. F.: The influence of dietary sulphate on the toxicity of lead in sheep, Proc. Nutr. Soc. 34A:77-78, 1975

22. Quarterman, J., Humphries, W. R., Morrison, J. R.: The influence of sulphur compounds on the availability of lead to rats, Proc. Nutr. Soc. 35 A:33-34, 1976

23. Castellino, M., Aloj, S.: Kinetics of the distribution and excretion of lead in the rat, Br. J. Industr. Med. 21:308-314, 1964

24. Sundewicz, J. J.: Lead lines at the iliac crest and early diagnosis of lead poisoning, Am. J. Med. Sci. 267:49-51, 1974

25. Altshuller, L. F., Halak, D. B., Londing, B. H., Kehoe, R. A.: Deciduous teeth as an index of body burden of lead, J. Pediatr. 60:224-229, 1962

26. Brudevold, F., Aasenden, R., Srinivasian, B. N., Balhos, 
Y.: Lead in enamel and saliva, dental caries and the use of enamel biopsies for measuring past exposure to lead, $\mathbf{J}$. Dent. Res. 56:1165-1171, 1971

27. Sonnabend, E., Bunzel, K., Kracke, W.: Die Vorteile der Bestimmung von Umwelteinflüssen durch Blei und Cadmium im Bereich des Gebisses und das Verhalten dieser Werte bei den verschiedenen Parodontopathien, Quintessenz 4:119-124, 1978

28. Needleman, H. L., Turnay, O. C., Shapiro, I. M.: Lead levels in deciduous teeth of urban and suburban american children, Nature 235:111-112, 1972

29. Shapiro, I. M., Needleman, H. L., Tuncay, O. C.: The lead content of human deciduous and permanent teeth, Environ. Res. 5:467-470, 1972

30. Strehlow, C. D., Kneip, T. J.: The distribution of lead and zinc in the human skeleton, Am. Ind. Hyg. Assoc. J. 3e:372-378, 1969

31. Shapiro, I. M., Dobkin, B., Tuncay, O. C., Needleman, H. L.: Lead levels in dentine and circumpulpal dentine of deciduous teeth of normal and lead poisoned children, Clin. Chim. Acta 46:119-123, 1973

32. Posner, H. S.: Indices of potential lead hazard, Environ. Health Perspect. 19:261 $-284,1977$

33. Benson, G. I., George, W. H. S., Litchfield, M. H., Seabora, D. J.: Biochemical changes during the initial stages of industrial lead exposure, Br. J. Ind. Med. 33:29-35, 1976

34. Haeger-Aronsen, B., Abdulla, M., Fristedt, B. I.: Effect of lead on 8-amino-levulinic acid dehydrase activity in red blood cells, Arch. Environ. Health 23:440-445, 1971

35. Yen, P. K. J., Shaw, J. H.: Remodeling of compact bone studied with lead acetate as an intravital stain, J. Dent. Res. $56: 961-966,1977$

36. Kato, Y., Takimoto, S., Ogura, H.: Mechanism of induction of hypercalcemia and hyperphosphatemia by lead acetate in the rat, Calcif. Tissue Res. 24:41-46, 1977

37. Bridges, J. B., McClure, J.: Experimental calcification in a number of species, Calcif. Tissue Res. 10:136-141, 1972

38. Kato, Y., Ogura, H.: Mineral phase in experimental ectopic calcification induced by lead acetate in the rat, Calcif. Tissue Res. 25:69-74, 1978

39. Windler, E. C., Smith, R. B., Bryan, W. J., Woods, G. W.: Lead intoxication and traumatic arthritis of the hip secondary to retained bullet fragments, J. Bone Joint Surg. 60A:254-255, 1978

40. Müller, M.: Die Fällung und die röntgenographische Untersuchung des Mischkrystallsystems $\mathrm{Ca}_{10}\left(\mathrm{PO}_{4}\right)_{6}(\mathrm{OH})_{2}-$ $\mathrm{Pb}_{10}\left(\mathrm{PO}_{4}\right)_{6}(\mathrm{OH})_{2}$, Helv. Chim. Acta 30:2069-2080, 1947

41. Narasaraju, T. S. B., Singh, R. P., Rao, V. L. N.: A new method of preparation of solid solutions of calcium and lead hydroxylapatites, J. Inorg. Nucl. Chem. 34:2072-2074, 1972

42. Rao, S. V. C.: Physicochemical studies of calcium-lead hydroxylapatites, Part III, J. Indian Chem. Soc. 53:352354, 1976

43. Engel, G., Krieg, F., Reif, G.: Mischkristallbildung und Kationeordnung im System Bleihydroxylapatit-Calciumhydroxylapatit, J. Solid State Chem. 15:117-126, 1975

44. Driessens, F. C. M.: Thermodynamics and defect chemistry of some oxide solid solutions. Part III. Defect equilibria and the formation of pair interactions, Ber. Bunsenges. Phys. Chem. 72:1123-1133, 1968

45. Posner, A. S., Perloff, A.: Apatites deficient in divalent cations, J. Res. Nat. Bur. Stand. 58:279-286, 1957

46. Engel, G.: Infrarotspektroskopische und röntgenographische Untersuchungen von Bleihydroxylapatit, Bleioxyapatit und Bleialkaliapatiten, J. Solid State Chem. 6:286-292, 1973

47. Young, R. A.: Biological apatite versus hydroxyapatite at the atomic level, Clin. Orthop. 113:249-262, 1975

48. Heijligers, H. J. M., Driessens, F. C. M., Verbeeck, R. M. H.: Lattice parameters and cation distribution of solid solutions of calcium and strontium hydroxyapatite, Calcif. Tissue Int. 29:127-131, 1979

49. Engel, G.: Hydrothermalsynthese von Bleihydroxylapatiten, Naturwissenschaften 57:355, 1970

50. Bhatnagar, V. M. Synthesis, X-ray and infrared studies of lead phosphates, Rev. Roum. Chim. 16:1513-1528, 1971

51. Wright, G.: Contribution à l'étude de l'influence des substitutions cationiques sur les propriétés d'échangeur d'ions des apatites, Ann. Chim. 5:39-62, 1970

52. Negas, T., Roth, R. S.: High temperature dehydroxylation of apatitic phosphates, J. Res. Nat. Bur. Stand. 72A:783787,1968

53. Blakeslee, K. C., Condrate, R. A.: Vibrational spectra of hydrothermally prepared hydroxyapatites, J. Am. Cer. Soc. 54:559-563, 1977

54. Brixner, L. H., Foris, C. M.: Crystal growth and X-ray data of the lead phosphates $\mathrm{Pb}_{4} \mathrm{P}_{2} \mathrm{O}_{9}$ and $\mathrm{Pb}_{8} \mathrm{P}_{2} \mathrm{O}_{12}$, J. Solid State Chem. 7:149-154, 1973

55. Skinner, H. C. W.: Phase relations in the $\mathrm{CaO}-\mathrm{P}_{2} \mathrm{O}_{5}-\mathrm{H}_{2} \mathrm{O}$ system from $300^{\circ} \mathrm{C}$ to $600^{\circ} \mathrm{C}$ at $2 \mathrm{~kb} \mathrm{H}_{2} \mathrm{O}$ pressure, Am. J. Sci. 273:545-560, 1973

56. Driessens, F. C. M.: Thermodynamics of the solubility behaviour of fluorhydroxyapatite solid solutions, Ber. Bunsenges. Physik. Chem. 83:583-586, 1979

57. Sudarsanan, K., Young, R. A.: Structure of strontiumhydroxyphosphate, Acta Cryst. B28:3668-3670, 1972 